Kaygl, 18(1)/2019: 20-36. Araştırma Makalesi | Research Article

Makale Geliş | Received: 17.11.2018

Makale Kabul | Accepted: 27.12.2018

Yayın Tarihi | Publication Date: 15.03.2019

DOI: 10.20981/kaygi.505624

Yakup HAMDİĞLU

Dr. Öğr. Üyesi | Assist. Prof. Dr. Cumhuriyet Üniversitesi, Edebiyat Fakültesi, Felsefe Bölümü, Sivas, TR Cumhuriyet University, Faculty of Letters, Department of Philosophy, Sivas, TR ORCID: 0000-0001-6117-5259 yhamdioglu@cumhuriyet.edu.tr

\title{
Hume: Estetik Değer Biçmenin İki Yönü
}

\section{$\ddot{O} z$}

Hume'un zihninde beğeni sorununun nasıl çözümlendiğini keşfedebilmenin en kestirme yolu, onun Beğeni Standardı Hakkında (Of the Standard of Taste) başlıklı denemesinde açtığı kapıdan girmektir. O, bu çalışmada, açık bir biçimde, estetik değer biçmenin öznel bir doğası olduğunu iddia etse de, beğeni yargılarının değerlendirilmesine zemin hazırlayan bir beğeni standardına ulaşmayı hedefler. Onun bu girişimi, böylece, beğeni anlaşmazlıklarını çözüme kavuşturmak bir yana, beğeni sorununu içinden çıkılmaz bir hale getirmiştir. $\mathrm{Bu}$ bakımdan, Beğeni Standardı Hakkında'nın onu dezavantajlı bir konuma yerleştirdiği eleştirmenler tarafından sıklıkla dile getirilir. Yine de insan anlayıșı onun çabasını izah eden felsefi/düşünsel bağlamın taslağını çizer. Buna bağlı olarak, beğeni yargıları öznel bir değere atıfta bulunsa da, insan doğasının evrensel ilkeleri bir beğeni standardının varlığını daha anlaşılır hale getirmektedir. Bu çalışma, ilk bölümde, Hume'un beğeni teorisindeki estetik değeri belirleyen öznel çerçeveyi açık kılmayı hedeflemektedir. İkinci bölümde, ilk bölümde elde edilen sonuçlar çerçevesinde, beğeni standardının, onun teorisinde, evrensel insan doğası ile aynı doğrultuda nasıl karakterize edildiği izah edilecektir.

Anahtar Kelimeler: Duygu, Beğeni, İnsan Doğası, Güzellik, Beğeni Standardı.

\section{Hume: Two Directions of the Aesthetic Evaluation}

\begin{abstract}
The shortest way to discover how the problem of taste in Hume's mind was resolved is to enter through the door he opened in his essay, Of the Standard of Taste. Although he openly claims that aesthetic appraisal is a subjective nature in the essay, he aims to achieve a standard of taste that lays the groundwork for the evaluation of the judgements of taste. His attempt thus, let alone find a solution to disagreements of taste, makes the problem of taste worse. In this regard, it is often expressed by critics that Of the Standard of Taste places him in a disadvantageous position. Even so, his view on human being sketches the philosophical/intellectual context which accounts for his attempt. Correspondingly, even though judgements of taste attribute to a subjective value, the universal principles of human nature make an existence of the standard of taste more understandable. This study, in the first section, aims to crystallize the subjective framework, which designates the aesthetic value in Hume's theory of taste. In the second section, within the frame of the outcomes which are achieved in the former section, it will be elucidated, in his theory, how the standard of taste is characterized in line with the universal human nature.
\end{abstract}

Keywords: Sentiment, Taste, Human Nature, Beauty, the Standard of Taste. 


\section{Estetik Değer Biçmenin Öznelliği}

"Modern estetik teorinin en önemli kilometre taşlarından biri olarak kabul edilen" (Hünler 2011: 275) ve bu nedenle estetik üzerine en çok bilinen çalışmalardan biri olan Hume'un Beğeni Standardı Hakkında ${ }^{1}$ başlıklı denemesi, denemelerinden oluşan Dört Tez (Four Dissertations) üst başlıklı derlemesinin içinde 1757 yılında yayımlandı. Onun buradaki amacı deneyim-güzel bağlantısının insan doğasında nasıl kurulduğuna 1 şık tutabilmekti. Beğeni sorunu kapsamında yapılan bu inceleme, beğeni ile ilgili tartışmalara son verecek bir takım ilkeleri ortaya çıkardığında bu hedef gerçekleşmiş olacaktı. Deneme Hume'un amaçlarına ulaştı̆̆ burada ileri sürdüğü düşünceler hem felsefesinin hem de farklı çalışmalarında dile getirdiği konu hakkındaki genel tavrının iç yüzünü yansıtır niteliktedir. Bu çerçevede düşünüldüğünde, "Hume’un genelde empirist, sensualist, relativist, nominalist felsefi tavrıyla koşullanan bir ilgi ve yakınlık duyduğu estetik söylem modeli, bu denemede hem yapısal olarak küçük ölçekte tekrarlanır hem de bizzat estetiğe özgü 'beğeni' sorunu temelinde özgül olarak yeniden inşa edilir.” (Hünler 2011: 278).

İnsanı öncelikle bir duyu varlığı olarak ele alan ve aklın "tutkuların kölesi” (the slave of passions) (Hume 1960: 415) olduğunu öne süren Hume için, beğeni sorununun ciddiyetle incelenmesi gereken bir konu olmasının yanı sıra, güzelliğin kaynağının haz ve acı deneyimi olmasının nedenleri gayet açıktır. O, 1739 yılında yayımlanan, felsefesinin çatısını oluşturan İnsan Doğası Üzerine Bir Inceleme (A Treatise of Human Nature) adlı eserinde şöyle yazar: "Tüm eylemlerinin başlıca kaynağı ve devindirici ilkesi olarak, insan zihninin içine bir acı ve haz algısı yerleştirilmiştir.” (Hume 1960: 118). Haz ve acı deneyimi hem insan zihnini eyleme geçiren başlıca ilkedir hem de duyumun öznel ve içsel yansımaları olan duygu ve tutkunun kaynağıdır: "Bu duyumlar hem düşüncemizden hem de duygumuzdan çıkarılırsa, büyük bir ölçüde, tutku ya da eylem, isteme ya da irade yeteneğinin dışında oluruz.” (Hume 1960: 574). Hume için duygu, burada beliren anlamıyla, gösterge ile gönderimi arasındaki bağıntıya ilişskin bir şey değildir. O sadece yaşanan göreli bir durumun anlatımıdır; "kendi dışında hiçbir

\footnotetext{
${ }^{1}$ Bundan sonra Deneme olarak kisaltılacaktır.
} 
şeye gönderme yapmamasıyla, hiçbir dişsallığa işaret etmemesiyle öznenin en sahici durumudur.” (Ferry 2012: 76). Bu eksende, Hume’a göre, "her duygu doğrudur; çünkü bir insanın onun bilincinde olduğu yerde duygu her zaman gerçektir ve kendisinin ötesinde hiçbir şeye bir gönderimde bulunmaz."2 (Hume 1998: 136). Hume güzelliği kendine özgü bir haz ve doyum veren ve tamamıyla duyguya ait bir estetik nitelik olarak tanımlar. "Bu, güzelliğin ayırt edici karakteridir ve onunla doğal eğilimi rahatsızlık üretmek olan biçimsizlik arasındaki tüm ayrımı oluşturur. Öyleyse haz ve acı güzellik ve biçimsizliğin sadece zorunlu katılımcıları değildirler, aynı zamanda onların gerçek özünü oluştururlar.” (Hume 1960: 299). "“Gerçekte nesnede olan şey” (what is really in the object) (Hume 1998: 136) hiçbir zaman duygu tarafından temsil edilmediği için güzellik ve biçimsizlik de nesnelere ait nitelikler olarak alınamazlar. Buna rağmen, "nesnelerde doğal olarak güzelliğin ve biçimsizliğin doğmasına yol açan kimi nitelikler" (Hume 1998: 141) estetik niteliklerin üretilmesinde iş başındadır. Bu bağlamda Hume, güzelliği "haz üreten bir biçim" (a form which produces pleasure); biçimsizliği de "ac1 ileten bir parçalar yapısı" (a structure of parts which conveys pain) olarak tanımlar (Hume 1960: 299). Tüm etkisi duyumun haz üretme gücünden türetilen güzellik, "yalnızca ruhtaki bir tutku ya da izlenim" (merely a passion or impression in the soul) (Hume 1960: 301) olmanın dışında başka hiç bir içeriğe sahip değildir. Öyleyse o, yalnızca şeyler üzerinde düşünen zihinde var olur; her zihin farklı bir güzelliği algılar (Hume 1998: 136-137). Bu ifade, ilk bakışta, güzelliğin bir beğeni duygusu olduğu düşüncesini dışlayan bir izlenim verir. ${ }^{4}$ Ancak güzelliğin nesnenin bir niteliği

\footnotetext{
${ }^{2}$ Hume şöyle devam eder: “Ancak anlama yetisinin tüm belirlemeleri doğru değildir; çünkü onlar kendilerinin ötesinde bir şeye, yani, gerçek olguya, bir gönderimde bulunurlar; ve her zaman bu standarda uymazlar." (Hume 1998: 136). Anlama yetisinin belirlemeleri ile karşılaştırıldığında estetik haz yalnızca öznenin duygusunu ve beğenisini anlattığ 1 için onun en sahici durumuna gönderimde bulunur. Böylece estetik duyguların anlatımı olan estetik yargılar arasında ayrımlar kaçınılmazdır. Bununla birlikte estetik yargıların Hume'un öne sürdüğü anlamdaki doğruluğu, estetik duyguların işlemesinde belli bir temel anlaşmanın bulunduğuna işaret eder gibi görünmektedir. Bu nedenle "sahici duygular olmak kaydıyla, duyguların tasviri yanıltmayacağı içindir ki, güzel olan, bilimin makul biçimde talip olamayacağı biçimde sağduyu konusu olabilir. Hume’un gayet mantıklı olarak estetik düşüncesinin çıkış noktası olarak kabul ettiği görececi duyumculuk burada yerini evrenselciliğe bırakır.” (Ferry, 2016: 77)

${ }^{3}$ Benzer şekilde ahlaksal ayrımlar söz konusu olduğunda da Hume, hazzın doğası gereği iyi, acının ise kötü olduğunu verili olarak kabul eder.

${ }^{4}$ Hume'a göre, beğeni sadece olduğu şeydir. Beğeni deneyimi doğrudan izlenimlere anında bir tepki olarak oluşur. Bu nedenle "doğruluk tartışmaya açıktır, ama beğeni değildir: Şeylerin doğasında var olan
} 
olmadığını söylemek, Hume’un İnsan Doğası Üzerine Bir İnceleme’de açıkladı̆̆ şekliyle, güzelliğin ikincil bir izlenim olduğunu söylemektir (Townsend 2001: 195). Bu noktayı daha anlaşılır kılmak için izlenim terimini belirginleştirmek gerekir. Hume’a göre izlenim bilincinde olduğumuz tek şeydir. Verilişinin dişında onu tanımlamak mümkün değildir. Bu nedenle Hume şöyle yazar: "İzlenim terimi ile işittiğimizde veya gördüğümüzde veya hissettiğimizde veya sevdiğimizde veya nefret ettiğimizde veya arzuladığımızda veya da istediğimizde daha canlı olan algılarımızın hepsini ifade ediyorum.” (Hume 1921: 15). "Zihne giren her şey, gerçekte algı" (Hume 1960: 190) ve “zihnin en canlı algıları da izlenimler" (Hume 1960: 208) olduğundan izlenim sadece dıştan gelen etkinin izi değil, aynı zamanda zihnin algılamasının kendisidir. Hume zihnin algılarını izlenim ve düşünce olarak ikiye ayırır. Buna göre bir izlenim ilk önce duyulara çarpar haz ya da acı duyumuna neden olur, daha sonra zihin tarafından onun kopyası alınır. Hume bunu düşünce (idea) olarak adlandırır. Buna uygun olarak da izlenimleri duyum (birincil veya orijinal) izlenimleri ve düşünme (ikincil) izlenimleri olarak ikiye ayırır. Bu ayrımlara göre izlenimlerin zihne verilişleri şöyle bir şema ile gösterilebilir: "Duyu nesnesi $\rightarrow$ duyu izlenimi $\rightarrow$ duyu idesi $\rightarrow$ duyu idesinin ruhta yansıması $\rightarrow$ düşünme izlenimi $\rightarrow$ düşünme idesi." (Nutku 2016: 41). Güzellik haz ya da acı düşüncesinden doğan bir izlenim olduğu için orijinal izlenime göre ikincildir. Bu bağlamda güzelliğin yalnızca şeyler üzerinde düşünen zihinde var olduğunu ya da bir düşünüm izlenimi olduğunu söylemek Hume’u problemli bir konuma yerleştirmez, çünkü onun amacı sadece güzelliğin izlenimler tarafından türetilen bir duygu ya da tutku olduğunun hesabını vermektir. Sonuç olarak güzellik, Hume'un zihninde, bir duyum izleniminden ileri gelen duygu üzerine kurulan - "parçaların düzeni ve yapısı" (an order and construction of parts) doğrultusunda - ve "ruha haz ve doyum veren" bir düşünme izlenimidir (Hume 1960: 299). Güzellik ikincil bir izlenim, duygu ya da tutku olduğuna göre, "gerçek güzelliği ya da gerçek biçimsizliği aramak, gerçek tatlıyı veya gerçek acıyı tespit etme iddiasında olmak kadar nafile bir araştırmadır.” (Hume 1998:

şey yargımızın standardıdır; her kişinin kendi içinde hissettiği şey duygunun standardıdır. Geometrideki önermeler kanıtlanabilir; fizikteki sistemlere itiraz edilebilir; ancak dizenin ahengi, tutkunun sıcaklığı, ince zekânın parlaklığı dolaysız haz vermelidir.” (Hume 1912: 3). 
137). $\mathrm{Bu}$ çerçevede, estetik değeri karakterize etmenin tek yolu güzelliğin insan doğasındaki empirik temellerini incelemektir. Hume'un yöntemi de buna göre şekillenir: Farklı çağ ve uluslarda hoşlanma duygusuna yol açan şeye ilişkin genel gözlemlerden yola çıkarak beğeninin evrensel olarak bağlandığı ilkelere ulaşmak. Ayırt edici özellikleri hazlar ve acılar tarafından tayin edilen belirli duygusal reaksiyonlar, burada, estetik niteliklere karar verilmesini sağlayacak empirik kaynaklar olarak ele alınırlar. $\mathrm{Bu}$ bağlamda düşünüldüğünde, apaçık bir biçimde, kompozisyonun kurallarının hiçbiri a priori uslamlamalar tarafından tayin edilemez: "Onların altyapısı tüm pratik bilimlerin, deneyimin altyapısıyla aynıdır; ne de onlar her çağda ve her ülkede evrensel olarak hoşnut edici bulunan şeye ilişkin genel gözlemlerden başka bir şeydir.” (Hume 1998: 137-138). Hume sanatın genel kurallarının da, insanların bütün hissiyatlarının bu kurallarla uyumlu olması söz konusu olmasa da, "deneyim ve insan doğasının ortak duygularının gözlemi” (Hume 1998:138) üstüne kurulduğunu düşünür. Çünkü sağduyu (common sense) göstermiştir ki, uygun koşullar oluştuğunda hoş duygular uyandırmaya doğal olarak uygun olan güzellikler enerjilerini hemen açı̆ga çıkarırlar (Hume 1998: 139). Hoş duygular uyandıran güzellikler, dünya döndükçe, insanların zihinlerindeki yetkelerini sürdürürler: "İki bin y1l önce Athena'da ve Roma'da hoşa giden aynı Homeros, Paris’te ve Londra'da hala beğenilmektedir. İklim, yönetim, din ve dildeki tüm değişimler onun ihtişamını gölgeleyememiştir." (Hume 1998: 139). Evrensel çürütülmeye karşı estetik değerin gösterdiği direnç, bilimsel bilgi ve felsefi bilgi karşısında onun konumunu daha güçlü kılmaktadır. Şöyle ki, bilim adamlarının ve fillozofların birbirlerine boyun eğmeleri ile karşılaştırıldığında, bir şiirin güzelliğinin insanların zihinleri üzerinde evrensel ve tartışmaya yer bırakmayan bir kalıcılığa sahip olduğu gün gibi ortadadır: “Cicero'nun soyut felsefesi itibarını kaybetmiştir: Onun hitabetinin coşkunluğu hala hayranlığımızın nesnesidir.” (Hume 1998: 149). Hume, bu kapsamda, şüphecilerin bağlandiğ1 "beğenilerin doğal eşitliği ilkesinin" (the principle of the natural equality of tastes) aldatıcı bir içeriğe sahip olduğu görüşündedir. Şu sözleri düşüncelerinin gerekçesi niteliğindedir: "OGILBY ve MILTON veya BUNYAN ve ADDISON arasında deha ve zarafet bakımından bir aynılık olduğunu iddia eden kim olursa olsun, bir köstebek yuvasının TENERIFFE 
kadar yükssek ya da bir küçük su birikintisinin okyanus kadar engin olduğunu iddia eden biri kadar bir mantıksızlığı savunduğu düşünülecektir.” (Hume 1998: 137). Bu ifadelerde çıkan sonuç şudur: Her beğeni yargısının ilkesini kendi içinde taşıması söz konusu değildir; o halde, beğeni yargılarındaki niteliksel farklar reddedilemez. Her bireyin beğenisinin aynı düzeyde olmadığ 1 evrensel duygu (universal sentiment) yoluyla da onaylanır ki, Hume buna dayanarak beğenilerin doğal eşitliği ilkesi karşısında bazı insanların diğerlerinin üstünde bir tercih hakkına sahip olduğunun kabul edilebilir bir yaklaşım olduğunu düşünür (Hume 1998: 148). Hume'a göre, beğeni yargılarındaki büyük çeşitliliğinin karşısında evrensel duygu, bize, bir çelişki ve saçmalığa düşmemek adına, "duygu hissiyatlarına bir miktar anlama yetisinin ışığını karıştırmak" (Hume 1998: 140-141) hususunda makul bir neden sağlamaktadır. Bu perspektiften değerlendirildiğinde, duyguları açık seçik bir biçimde karşılaştırarak güzelliği ve biçimsizliği oluşturan her bir parçayı ayırt edebilecek kişiler, toplumda, sağlam kavrayışları ve yetilerinin yetkinliği bakımından diğerlerine göre kolayca ayırt edilebilirler. Çünkü güzellik deneyimi insanoğlunun doğal yapısında - "içsel dokunun özgün yapısı" (the original structure of the internal fabric) (Hume 1998: 140) - salt hoşlanma duygusu olarak yaşanan bir süreç değildir, aynı zamanda zihnin bütün işlemleri de burada iş başındadır. Bundan dolayı, estetik niteliklerin şekillenmesi için, öncelikli olarak, gerçekte nesnede olan şeyin imgeleme duyu ve algı yoluyla doğru bir biçimde - herhangi bir engele (sağlı, önyarg1 v.b.) takılmadan - yansıtılması gerekir. Hume'un felsefesinde imgelem, ilk anlamıyla, zihnin işleyişinde "imge üreten yetinin" (the image-making faculty) kavramsal karşılığıdır (Warnock 1978: 15). O, izlenimlerin yinelenmesini sağlar; böylece, izlenimler zihne düşünceler olarak sunulurlar - ki izlenimler bulunmadıklarında da onun aracılığıyla onlarla ilgili şeyleri düşünebiliriz. ${ }^{5}$ Burada imgelem ve duygu durumları arasında da sıkı bir yakınlık vardır. Daha açık bir ifadeyle, yukarıdaki şemada da gösterildiği gibi, duyulardan sağlanan birincil izlenimler duyu izlenimleridir; düşüncenin ruhta yansıması sonucu oluşan ikincil izlenimler ise tutku, istek, isteksizlik, umut ve korku ve diğer duygusal reaksiyonların oluşmasına

\footnotetext{
${ }^{5}$ Hume'a göre, bu bağlamda, "imgelemin evreninde" (the universe of the imagination) üretilenden başka bir herhangi bir düşüncemizin olması veya oluşması da mümkün değildir (Hume 1960: 68).
} 
kaynaklık eden düşünme izlenimleridir. Hume şöyle yazar: "Dikkat çekicidir ki canlı tutkular yaygın bir şekilde canlı bir imgeleme eşlik ederler." (Hume 1960: 427). Canlı bir imgenin, doğası itibariyle, bir tutku ile ilişkili olma olasılığı sönük bir imgeden daha yüksek olduğu gibi zihindeki daha canlı ve ayrıntılı bir tasvir de daha yoğun bir duygu durumuna yol açacaktır (Warnock 1978: 38). Bu bakımdan Deneme'de "imgelemin inceliğgi" (the delicacy of imagination) daha ince duyguları algılama ve ayırt etme yeteneği için gerekli bir koşul olarak ifade edilir (Hume 1998: 140). Böyle bir incelikten yoksun olma gerçek güzellik deneyiminin yaşanmasının önünde büyük bir engeldir. Çünkü imgelemin inceliğinden yoksun olan bir kişi beğeniyi ve duyguyu kendi ölçütüne indirmekte sakınca görmeyecektir. Hume bu noktada Cervantes'in Don Kişot'ta Sancho’ya anlattırdığı bir öyküyü bu düşüncelerini gerekçelendirecek bir örnek olarak verir.

Hikâye Sancho'nun aile yakınlarının eski olduğu için çok kaliteli olduğu düşünülen bir fıçı şarap hakkında yargılarının haklı çıkması ile ilgilidir: Sancho'nun yakınlarından biri şarabı tattıktan sonra onun iyi olduğunu ama kösele tadı aldığını dile getirmiş; diğeri ise, kolaylıkla aldığı hafif bir demir tadı saklı kalmak kaydıyla, aynı yargıya varmış. Günün sonunda, fiçı boşaltıldığında, fiçının dibinde kösele kayışa bağlı demirden bir anahtar bulunmuştur. Bu hikâyeden çıkan ilk sonuç şudur: "Zihinsel ve fiziksel beğeni arasındaki büyük benzerlik" (Hume 1998: 141) estetik niteliklerin oluşmasında kurucu bir bileşendir. Şöyle ki, Hume'un bakış açısından, Sancho'nun aile yakınlarının yargılarını haklı çıkaran unsur, onların duyularının tatların hiçbirisini kaçırmayacak kadar duyarlı; zihinlerinin veya imgelemlerinin ise şarabın yapısında veya bileşimindeki niteliklerle birlikte onların ürettiği her duyguyu algılayacak kadar keskin olmasıdır. Hume'un estetik düşüncesinde, bu bağlamda, estetik deneyimin oluşması için söz konusu parçaları bir araya getirebilme yetkinliği "beğeni inceliği”" olarak adlandırılır. $\mathrm{Bu}$ yeteneği olan kişilerin duyguları, nesnenin yapısındaki/bileşimindeki (composition) veya tasarımındaki (design) her içerikten gözle görülür biçimde etkilenecek - doyumla (satisfaction) algılayacak - şekilde incelmiştir. Güzelliği algılamada ustalık anlamına gelen beğeni inceliği, Hume için, hem estetik 
niteliklerdeki ayrımı somutlaştırmaktadır ${ }^{6}$ hem de estetik deneyimin bir takım genel kurallara bağlı gerçekleştiğini düşünmek için bir altyapı sağlamaktadır (Hume 1998: 141). Onun beğeni sorununa karşı yaklaşımı olgusal/empirik olduğu için o, güzelliğin genel kurallarına (the general rules of beauty) özneden ayrı bir genelliğ $\mathrm{e}^{7}$ işaret eden bir içerik yüklemez. Böyle bir empirik genelliğe kapı aralayan öznellik de, dolayısıyla, beğenilerin doğal eşitliği ilkesinde değil, nesnenin kendisinde olan şey (yapısında/bileşiminde veya tasarımında) ile kendine özgü duygusal reaksiyon arasında imgelemde kurulan ilişkilerde anlamını bulmaktadır. ${ }^{8}$

\section{II. İnsan Doğasının Evrenselliği Yönünde Estetik Değer Biçmek}

Beğeni sorunu Hume'un zihninde, şüphesiz, bir beğeni standardı sorunudur: "Bir beğeni standardı araştırmak bizim için doğaldır; insanların çeşitli duygularını uzlaştırabilecek bir kural; en azından bir duyguyu onaylayan bir başkasını kınayan bir karar." (Hume 1998: 136). Beğeninin standardını araştırmak doğaldır çünkü insanların duyguları genellikle her çeşit güzellik ve biçimsizlik bakımından sıklıkla farklılaşırlar (Hume 1998: 134). Hume'un beğeni teorisinde güzellik deneyimi haz duygusu ekseninde şekillenir ve böyle olduğu için de kendi içine kapalıdır. Bu durumun güzellik üzerine inceleme yapmayı tamamen sonuçsuz bir çaba durumuna getirmesi beklenirken Hume, çeşitli duyguları uzlaştıran evrensel kuralları saptamaya çalışmıştır. Ona göre, insanoğlunun deneyimleri göstermiştir ki, diğerlerinin karşısında hoşlanma duygusu uyandırmaya elverişli güzellikler, uygun koşullar oluştuğunda, aynı eğilime yol açmaktadırlar. Belirli bir hoşlanmaya yol açan kimi niteliklerin tanınmasındaki beceri, bu güzelliklere karşı beğeni inceliği kazanmanın önemli bir parçasıdır. Hume’un estetik

\footnotetext{
${ }^{6}$ Hume'a göre, beğeni inceliğine sahip bir kişi için "kibar ve akla uygun bir konuşma ona en yüksek eğlenceyi sağlar; kabalık veya küstahlık ona o kadar büyük cezadır. Kısacası, beğeni inceliği tutku inceliği ile aynı etkiye sahiptir. O (beğeni inceliği) hem mutluluğun hem de sstırabın alanını genişletir ve bizi insanlığın geri kalanının gözünden kaçan hazlara olduğu kadar acılara da duyarlı kılar.” (Hume 1998: 10-11).

${ }^{7}$ Hume felsefesinde bu genellik insan doğasının doğayla uyumunu anlatmaktadır.

${ }^{8}$ Burada vurgulamak gerekir ki, bu ilişkiler imgelem tarafindan kurulmazlar ama çağrışım ilkeleri (benzerlik, bitişiklik ve nedensellik) yoluyla imgelemde kurulurlar. Esasında, "hiç̧bir şey imgelem tarafindan yapılmaz; her şey imgelemin içinde yapılır. İmgelem tarafından bir düşüncenin üretilmesi sadece imgelemde bir izlenimin yeniden üretilmesi olduğu için imgelem düşünceler oluşturan bir yeti bile değildir." (Deleuze 2001: 23).
} 
düşüncesinin temel dinamiklerinden olan beğeni inceliği, estetik değer biçmenin öznelliğine rağmen, onun için, güzelliğin genel kuralları düşüncesine kapı aralar. Burada onun zihnindeki soru şöyledir: Beğeni inceliği nasıl insan doğası haline gelmektedir? Diğer bir ifadeyle, insan doğası nasıl güzelliğe duyarlı hale gelmektedir? Beğenilerle ilgili bir inceleme, eğer başarısız bir girişim olmayacaksa, estetik değeri karakterize etmeye yönelik bir belirlemeyi zorunlu kılar. Hume beğenilerde karşılaşılan büyük çeşitliliğii, insan-doğa ilişkisinin dışında resmedilen nesnel bir estetik değer anlayışını olumsuzlayan bir kanıt olarak görür. Onun amacı, deneyimin estetik değer biçmede insanoğlunu nasıl yetkinleştirdiğinin arka planını felsefi olarak izah edebilmektir. Radikal deneyciliğine karşın, beğeni yargılarının geçerliliğini ölçebilecek bir karar mekanizmasının evrensel olduğunu düşünmesi nedeniyle, Hume’un Deneme'de sergilediği uslamlamada kendimizi zor bir bilmecenin içinde hapsolmuş gibi hissedebiliriz. Ancak bunun da nedenleri vardır ve Hume'un problemli görünen beğeni standardı arayışı, tüm çıkmazlarına rağmen, insan görüşü ekseninde anlaşıldığında anlamsız bir çaba değildir. Beğeni sorununun yol açtığı güçlükler karşısında Hume, beğeninin evrensel ilkeleri için ihtiyaç duyduğu temeli insanoğlunun özsel yapısında bulur: "Beğeninin genel ilkeleri insan doğasında yeknesaktır." (Hume 1998: 149). Genel bir ifade ile Hume'un "insan doğası" kavramı, onun felsefesinin temeli olan insan-doğa birlikteliğine gönderme yapar. Kavram, daha özelde, bir taraftan insanın doğal yapısının "değişik algıların bir demeti" (a bundle or collection of different perceptions) (Hume 1960: 252) olduğuna; diğer taraftan ise, ilkinden daha önemli bir biçimde, doğanın düzenine uygun bir şekilde evrensel ilkeler (deneyim ve alışkanlık ilkeleri, çağrışım ilkeleri ve tutku ilkeleri) tarafından kurulduğuna işaret etmektedir. Hume, bu ilkeler 1şığında, geçmişte nasılsa gelecekte de o şekilde kalacak bir insan doğasının değişmezliğinin özsel olduğuna inanmaktadır: "Bütün uluslarda ve çağlarda insanların eylemleri arasında büyük bir yeknesaklık (uniformity) olduğu ve insan doğasının ilkeleri ve işlemlerinde hep aynı kaldığı evrensel olarak kabul edilir." (Hume 1921: 85). İnsan doğası bütün çağ ve bölgelerde o kadar evrenseldir ki, tarihin bu konuda "insanın doğasının tüm bilinen ilkelerini" (all the known principles of human nature) (Hume 1921: 95) yerinden oynatacak kadar aykırı ya da yeni bir şey söylemesi 
mümkün değildir. İnsana dair tarihte bir ilerlemeden söz edilecekse bu, "insan doğasının değişmez ve evrensel ilkelerini” (the constant and universal principles of human nature) (Hume 1921: 86) ortaya çıkarmak adına onun eylem ve davranışlarının değişmez kaynaklarını tanımamız ile ölçülebilir. İnsanı doğal yapısının ilkeleri konusunda eğiten ve geleceğe hazırlayan ise bir deneyim sürecinde biriktirdiği genel gözlemlerdir. Hume'a göre eğer insan doğasında yeknesaklık olmasaydı ve deneyim “düzensiz ve yasasız" (irregular and anomalous) olsaydı, o zaman insan üzerine genel bir gözlem elde etmek mümkün olmazdı (Hume 1921: 87-88). ${ }^{9}$ İnsan, doğasındaki düzen nedeniyle geçmiş deneyimlerini hâlihazırdaki duyu izlenimlerine aktarma yatkınlığındadır. Hume için bu yatkınlığın kökeni olan alışkanlık, deneyimlerimiz arasında zorunlu değil ama olasılıklı bir ilişski olduğunu gösteren doğanın ilkelerinden başka bir şey değildir (Hume 1960: 179). Doğal olarak tüm düşünceler duyu izlenimlerinden doğduğu ve tüm yargıların temelinde öznel bir gereklilik, inanç ${ }^{10}$ (belief) veya alışkanlık yer aldığı için akıl yürütmelerin tamamı geçmiş deneyimler ile uyum içinde sonuçlar ortaya koymaya dayanır. Alışkanlık, o halde, insan hayatının yüce kılavuzudur. Deneyimimizi bize yararlı kılan ve gelecekte geçmişte ortaya çıkmış olaylara benzer bir olaylar zincirini beklememizi sağlayan tek başına bu ilkedir (Hume 1921: 45). Hume’a göre alışkanlık ilkesi, olgu sorunları (matters of fact) ve varoluş (existence) hakkındaki tüm akı1 yürütmelerimizde zihnimiz işlemlerini gerçekleştirmeye zaman bulmadan iş başındadır. Bu gösteriyor ki, burada, “doğanın akışı ile idealarımızın birbirini takip etmesi arasında bir çeşit önceden-kurulmuş harmoni” vardır (Hume 1921: 55). Alışkanlık ilkesi temelinde düşüncelerimiz ve kavramlarımız doğanın akışı ile aynı yolu izler. Ancak deneyim bilgisinin olasılığın tahakkümünde olması nedeniyle, neden böyle bir uyumun var olduğunun kesin bilgisine ulaşılamaz. Bu bağlamda alışkanlık insanoğlunun hayata tutunmasını, türünü devam ettirmesini ve her problem karşısında bir yol bulmasını

9 Buna rağmen Hume "olması gerek" tartışmasında olandan olması gerekene geçişin tamamen kavranamaz olduğu görüşündedir. $\mathrm{O}$, bu bağı bilgide olduğu gibi ahlak alanında da koparmasıyla (subjektifleştirmesiyle) tartışmada aşırı uçta yer aldı. Daha sonra bu bağı kurma görevini Kant üstlenecektir. Bu konuyla ilgili bir tartışma için Prof. Dr. Uluğ Nutku'nun İnsan Felsefesi Çalışmaları adlı kitabındaki “Olması Gerek” Üzerine Bir Tartışma başlıklı yazısına bakılabilir.

${ }^{10}$ Hume'a göre, inanç, bulunan bir izlenim ile bir ilişki (ya da çağrışım) yoluyla üretilen canlı bir düşüncedir (Hume 1960: 97). 
mümkün kılan ilke olmasına rağmen, bu bilinmezlik hiçbir zaman aşılamayacaktır. O halde, Hume, esasında, olgu ve varoluş sorunlarımızın doğasını deneyim ve alışkanlık ilkelerine başvurarak izah ederken, aynı zamanda da, olasılığı hayatı anlamanın gerçeği haline getirmiştir. Yine de, bu şüpheci tutumunun yanında, ona göre, eğer "insan doğasının doğru anatomisi” (the accurate anatomy of human nature) (Hume 1960: 263) çıkarılırsa, hem insan doğasının evrensel ilkelerini kesinleştirmek hem de onlara başvurarak kavramsal çerçevemizi nasıl oluşturduğumuzu izah etmek mümkün olacaktır. Böylece, bu durumun yol açtığı çelişkilere ${ }^{11}$ rağmen, Hume'un insan görüşünün ağırlık merkezini deneyim bilgisinin olasılığı değil, önceden-kurulmuş uyumun değişmezliği oluşturur. Hume, felsefi olarak, değişmezliğinin yapısal ve özsel olduğunu düşündüğü insan doğasının, tüm bilimlere biricik sağlam bir çekirdek olduğuna dair inancını daima korumuştur. Onun zihninde insan doğası ile uygunluk içinde izlenim, inanç, düşünce, alışkanlık, deneyim, neden-etki, bellek ve imgelem kavramları "tüm durumlarda deneyimimizi açıkça ya da gizlice, doğrudan ya da dolaylı olarak hiçbir deneylerini edinmediğimiz örneklere aktarırız" (Hume 1960: 105) ilkesi etrafında bir araya gelir. Deneyim, tarihsel süreçte, insanın geçmişi geleceğe bağlamasının, tam ve eksiksiz bir şekilde, alışkanlığını kazandırır. Hume alışkanlıktan aldığı güvence ile insan doğasının gelecekte de aynı algılama niteliğini devam ettireceğine olan inancını canlı tutar. Çünkü algıların düzenli ardışıklığı (the regular succession of perceptions) yoluyla olmanın dışında, zihne sunulmuş bir şey aracılığıyla alışkanlık kazanmak mümkün değildir (Hume 1960: 197). Nesneler "düzenli bir bitişiklik ve ardışıklık düzeni içinde" (a regular order of contiguity and succession) (Hume 1960: 87) var olurlar. Deneyim, buna bağlı olarak, tüm geçmiş durumlarda sürekli birarada (constant conjunction) bulunan tikel nesnelerin değişmez olarak birbirleriyle bağıntılı olduklarını bildirir. Hume'a göre geçmiş deneyim ve onların

11 Çelişki Hume'un izlenimler teorisindeki insan anlayışına sonuna kadar bağlı kalmamasından kaynaklanır. Çünkü onun izlenimler teorisine göre duyu izlenimleriyle edindiğimiz deneyimler arasında zorunlu bağlantı değil, sürekli biraradalık bulunur. Böylece geçmişteki deneyimlerimizden geleceğe dair objektif sonuçlar çıkaramayız çünkü deneyime dayanan bilgi olasıdır. "Fakat Hume'un insan görüşü böyle bir olasılığa dayanmıyor; çünkü değişmezliğin yapısal, özsel olduğunu söylüyor. Bu görüşünün evrensel olduğunu söylemekle de izlenimler teorisindeki insan anlayışından uzaklaşıyor." (Nutku 1998: 77). 
değişmez biraradalıklarını hatırlamamız, aynı zamanda, duyulara sunulan bir izlenimden neden ve etki düşüncesine geçişin kaynağıdır (Hume 1960: 88). Nedensel bağlantı hem sürekli biraradalık hem de ardışıklık (succession) ve bitişiklik (contiguity) ilişsilerine işaret eder. Hume’a göre, benzerlik (resamblance) neden-etki ilişkisiyle, neden-etki arasındaki benzerlik ilişkisi de deneyimle birleştiğinde zihin bir düşünceden ötekine geçme alışkanlığı kazanır. Başka bir ifade ile nesnelerin değişmez birliktelikleri ve ardışılık-bitişiklik ilişkilerinin kesintisiz benzerliği insan doğasında daima bir beklenti veya inanç olarak karşılık bulur. $O$ halde, zihin bir nesnenin düşüncesinden ya da izleniminden bir diğerinin düşüncesine ya da inancına geçtiğinde, akıl tarafından değil ancak bu nesnelerin düşüncelerini birarada çağrıştıran ve onları imgelemde birleştiren belli ilkeler tarafından belirlenir (Hume 1960: 92). Buradan çıkan önemli sonuçlardan biri şudur: Çağrışım ilkeleri özneler-arası paylaşıma açık bir "inanan özne" kurarlar. ${ }^{12}$ Hume'un felsefesinde, özne herhangi bir olayın nasıl gerçekleşeceğinin önceden belirlenmiş bir mutlaklığı tarafından değil, tasarımların akışını yöneten çağrışım ilkelerinin imgelemdeki birliği tarafından etkinleştirilmiş bir zihindir. İlkeler zihinde eyleme ${ }^{13}$ geçtiklerinde biz herhangi bir olayın başka türlü değil de düşündüğümüz şekilde gerçekleşeceğine bir alışkanlık, beklenti veya inanç geliştiririz. Bu noktada, buradakine benzer özneler-arası bir "doğal inanç" düzeninin Hume'un beğeni sorununun çözümünde de çalıştığını düşünmek mümkündür. Bu düşünce, onun bilgi anlayışının da dayanağı olan ve yeknesak (uniform) bir doğa etrafında yapılandırdığı insan görüşüne de uygundur. O, her duygunun kendi içinde doğru olduğu düşüncesi karşısında, insan doğasındaki yeknesaklığı beğeni standardını sağlayan zemin olarak alır. Bu doğrultuda beğeni standardını temellendirebilmek için yüksek düzeyde hoşlanma ya da hoşlanmama hissi uyandıran şeylerin özel olarak incelenmesi gerekir.

\footnotetext{
12 "Hume'a göre iki nesnenin sürekli olarak birarada bulunacağına inancımız, psişik-individuel bir inanç değildir, intersubjektivdir. Bu inanç insanların bir fantezisi değil, tabiatın onlara verdiği bir özelliktir. İnançların düzeni tabiatın düzenine uygundur. İnsanı bir tabiat varlığı gören Hume, inancın intersubjektivliğinin tabiattaki karşılığını aradı. Tabiattaki nesnelerin sürekli biraradalığından meydana gelen tabiat düzeninin karşılığg intersubjektiv inanç düzenidir.” (Nutku 2016: 54).

13 "Nedir onların eylemi? Cevap belirsizliğe yer vermez: İlkenin etkisi her zaman bir düşünme izlenimidir." (Deleuze 2001: 113).

14 "Hume'un deneysel akıl yürütmeye dayalı felsefesinin birinci ve en önemli hedefi, doğal inancı (natural belief) akılcı inanca karşı ön plana çıkarmak ve bunun haklılığını kanıtlamaktır.” (Taşkın 2007: 80).
} 
Hume'a göre, bu incelemede "güzelliğe duyarlı bir beğeninin" (a delicate taste of beauty) daima arzu edilen bir nitelik olarak alınması zorunludur. Çünkü o, insan doğasının duyarlı olduğu en güzel ve en masum beğenilerin kaynağıdır ve bu nedenle de estetik deneyimin nesnesidir. Hume şöyle devam eder: "Bu kararda tüm insanlığın duyguları birleşirler. Her nerede bir beğeni inceliği ortaya çıkarabilirseniz, onun kabul göreceğinden emin olabilirsiniz; ve bunu ortaya çıkarmanın en iyi yolu ulusların ve yüzyılların yeknesak onayı ve deneyimi tarafından belirlenmiş o ilkelere ve modellere başvurmaktır." (Hume 1998: 143). O halde, bu ilkelere nasıl ulaşacağız? Hume'un bakış açısından, beğeni yargılarında ulaştıkları incelikten dolayı "insanlığın geri kalanı üstünde kavrayışlarının sağlamlığı ve yetilerinin üstünlüğü itibarıyla toplumda kolayca ayırt edilen ince beğenili ender insanlar" (Hume 1998: 149) tartışmayı çözüme kavuşturacak bir "karar mekanizması" veya "otorite" olarak kabul edilmelidirler. Çünkü "en iyi bilirkişilerin yargıları içsel ve yarı-biologik insan doğasının en özsel teşekkülünde temelleniyorsa, bu yargılar tüm diğer yargılar için bir olması gereken düzlemini kurarlar.” (Hünler 2011: 290). Beğeni konusunda karar verme yetkesine sahip "gerçek bilirkişi”" (true judge) estetik nitelikleri kararlarında sabitleştirmesiyle diğerlerinden ayrılır. Deneyim ve alışkanlığın beraberce çalıştırdığg imgelem, belirli bir hoşlanma duygusunun meydana gelme sıklığına bağlı olarak, daha ince duyguları algılama ve ayırt etme yeteneği kazanmadan bu durum gerçekleşmez. Güzelliğin veya estetik değerin genel kuralı, bu durumda, duygulanımın imgelemde canlı ve güçlü bir biçimde yankılanmasıdır. Bunun için de "gerçekte nesnede olan şey" imgeleme doğru bir şekilde yansıtılmalıdır, çünkü estetik deneyim kendilerine özgü duygusal reaksiyonlar ile parçaların düzeni ve yapısı arasında imgelemde kurulan bağlantıda şekillenir. Göreli bağlamı dışlamayan bu nokta beğeni yargılarındaki niteliksel farklara işaret etmekle birlikte, hem "genelde bazı insanların diğerlerinin üstünde bir tercih hakkına sahip" (Hume 1998: 148) olmalarının hem de beğeni standardının insan doğası haline gelmesinin genel bir kuralı gibi anlaşılabilir. Buna bağlı olarak Hume, Deneme'de, iyi eleştirmenlerin (good critics) beğeni yargılarının farkını gösteren özelliklere açıklık kazandırır: Sağlıklı olma (wellness), her duyu ve yetinin yetkinliği (the perfection of every sense and faculty), üstün yeteneklilik (genius), gözlem 
(observation), tecrübe (practice), sağlam kavrayış (sound understanding) ve aklıselim (good sense). Hume için beğeniye dişsal olan bu unsurlara dayanmadan yargıda bulunmanın üstün güzelliklerle ilişki kurulmasına engel olacağını söylemek yanlış olmayacaktır. ${ }^{15}$ Hume'a göre gerçek eleştirmenler veya bilirkişiler, yukarıda saydığımız karakteristik özellikleri bakımından, her zaman nadir bulunan karakterlerdir. Onların ayırt edici özellikleri, beğeni konusunda önemli bir parçayı somutlaştırmalarından ve bunu yol gösterici bir etken olarak kararlarına yansıtmalarından gelmektedir. Eleştirmenlere değerli karakterler olma hakkı tanıyan bu nitelik, Deneme'de Hume tarafından şöyle ifade edilir: "İnce duyguyla birleştirilmiş, uygulamayla geliştirilmiş, karşılaştırmayla mükemmelleştirilmiş ve tüm önyargılardan temizlenmiş güçlü duyu." (Hume 1998: 147). ${ }^{16}$ Bu güçlü duyuya (strong sense) sahip olmaları çerçevesinde düşünüldüğünde, iyi eleştirmenler estetik nitelikler için sahip olduğumuz en iyi epistemik göstergelerdir (Kulenkampff 1990: 93-110). Hume'a göre, "her nerede bulunursa bulunsunlar, böyle kişilerin ortak kararı (the joint verdict) beğeni ve güzelliğin gerçek standardıdır." (Hume 1998: 147). ${ }^{17}$ Doğrudan iyi eleştirmenlerin karakterlerinde cisimleşen, diğer bir ifade ile onların somut varlığı olmaksızın söz konusu olmayacak nitelikler ortak kararı doğurur. ${ }^{18} \mathrm{Bu}$ nedenle iyi eleştirmenlerin ortak kararı olmaksızın bir beğeni standardından söz edilemez. Çünkü ancak iyi eleştirmenlerin güçlü duyu etrafında şekillenen ortak kararı beğeni yargılarının

\footnotetext{
${ }^{15}$ Hume en kaba türkülerin bile uyum ve doğadan tamamen yoksun olmadığını ancak üstün güzelliklerle tanışık bir kişinin onları beğenen insanları sert bulabileceğini veya onların anlatımlarının çekici olmadığını belirtebileceğini ifade eder (Hume 1998: 144).

${ }^{16} \mathrm{Bu}$ ifadelerinden hareketle, birçok çalışmada, Hume'un iyi bir eleştirmeni kötüsünden ayırt etmemizi sağlayan beş karakteristik özelliğe atıfta bulunduğu ifade edilir.

${ }_{17}$ Hume beğeni standardını bu şekilde açık bir ifade ile dile getirse de, standardın esasında ortak karara $\mathrm{m} ı$ dayandığı yoksa bir takım kurallar mı içerdiği onun eleştirmenleri arasında bir tartışma konusudur (Shelley 1994: 437-438).

${ }^{18}$ Bu noktada Hume'un akıl yürütmesinde bir kısır döngü ile karşılaşılır (Kivy 1960: 60, Wieand 1984: 138-139). Şöyle ki, iyi eleştirmenlerin ortak kararı beğeni standardıdır. Onların kararı bazı şeylerin güzel diğerlerinin ise biçimsiz olarak değerlendirilmesinde karar mekanizmasıdır. İyi eleştirmenler, burada, karakteristik özellikleri sayesinde beğeni konusunda değerli birer karakter oldukları tasdik edilmiş̧ kişilerdir. Peki, onların bu özellikleri yerine getirdiklerine nasıl karar verildi? Onların dışında herhangi birinin buna karar vermesini imkânsız kılar çünkü onların dışındakiler estetik değeri yalnızca onların yargıları temelinde bilirler. $\mathrm{O}$ halde, Hume döngüsel bir kanıtlama içinde beğeni sorununa bir çözüm getirmektedir. Yine de, Hume'un deneyciliği ve insan anlayışı çerçevesinde değerlendirildiğinde bu problem burada onun söylediği anlamda bir beğeni standardı olamayacağını göstermez.
} 
gelişmesine ve genelleşmesine imkân tanıyan bir estetik açıklık sağlayabilmektedir. ${ }^{19}$ Hume, eğer izlenimler teorisinde beliren insan görüşüne sadık kalsaydı, hiçbir şekilde böyle bir sonuca ulaşması mümkün olmazdı. Daha açık bir şekilde söylemek gerekirse, insanı "değişik algıların bir demeti” olarak ele alması karşısında insanın tek bir doğası olduğunu düşünmeseydi, o zaman bir doğalar çeşitliliği üzerinden gitmesi gerekirdi. Bu durumda da beğeni farklılıkları onu şüpheci filozofun kendini konumladığı noktaya götürürdü. Ancak Hume’a göre, insan "bir alg1 varlığg”,20 olsa da, insanoğlunun eylem hayatı gelişigüzel yapıp etmeler üzerine kurulmaz ve yapıp etmelerimizin ilkeleri, insan doğasının doğayla ters düşmediğinin en açık göstergesidir. Hume'un insan doğası düşüncesine göre, dolayısıyla, insanın “özü” değişen bir şey değildir; o halde, bir beğeni standardı araştırmasını ne anlamsız ne de gereksiz görülmemesi gerekir; çünkü beğeni anlaşmazlıkları karşısında insan doğasını doğayla uyumlu kılan ilkeler beğeni standardının varlığını onaylamanın teorik temellerini sağlarlar. ${ }^{21}$ Buna dayanarak, açık bir biçimde, iyi eleştirmenlerin ortak kararının, Hume için, "imgelem üzerinde işleyen alışkanlığın” (Hume 1960: 103) doğanın düzenine koşut deneyime başvurarak sağladığı özneler-arası inanç düzeninin beğeni düzleminde bir karşılığı olduğunu iddia etmek mümkündür.

\footnotetext{
${ }^{19}$ Buna rağmen Hume, her iki tarafın da tamamen kusursuz olduğu haliyle içsel yapı veya dışsal konumda bir farklılık durumunun taraflardan birinin beğenisini diğerine tercih etmeye yer bırakmadığını ifade eder. Ona göre böyle bir durumda belli bir yargı çeşitliliği kaçınılmazdır ve karşıt duyguların uzlaşmasına imkan verecek bir standardı boşu boşuna araştırırız (Hume 1998: 149-150). Onun bu düşüncesinin Deneme'yi sonuçsuz bir çaba durumuna getiren bir kabul ve itiraf olduğunu düşünmüyorum. Dahası bu, Deneme'nin bağlandığı sonuç da değildir. Hume'un beğeni standardı iyi eleştirmenlerin öznel yargıları değil, onların ortak kararıdır. Onun bakış açısından ortak kararı merkeze almak yanılma tehlikesini ortadan kaldırmak - en aza indirmek değil - anlamına gelir. Bu bağlamda Hume iyi eleştirmenlerin kim olduğuna değil, onların karakterlerinde cisimleşen niteliklere yoğunlaşır ve bu niteliklerde estetik açıklığı sağlayan yetkinlikler olarak değerlendirilirler. Belli bir yargı çeşitliliği kaçınılmazdır ancak Hume’un Don Kişot’tan aldığı örnek göz önüne alındığında anlaşılacaktır ki, iyi eleştirmenlerin ortak kararı beğeni tartışmalarında ihtiyaç duyulan eksik parçaları tamamlamaktadır. Bu eksik parçalar her örnekte değişse de, onların bu eksik parçaları tamamlamak için sahip oldukları nitelikler evrensel olarak tanınabilirler. Bu durumda, eğer belli bir yargı çeşitliliği bir beğeni yetersizliğine işaret ediyorsa, iyi eleştirmenlerin ortak kararı onun kusursuz olmadığını eninde sonunda, zamana ve deneyime bağlı olarak, kesinleştirecektir.

${ }^{20} \mathrm{Bu}$ tanımlamanın anlamı şudur: Algının son bulduğu yerde insanın bireysel varlığı da son bulur.

${ }^{21} \mathrm{Bu}$ anlamda, Hume'un beğeni teorisi beğeni standardı düşüncesini beğeni yetisine dayanarak onaylamaz; onda bulduğumuz şey insan doğasına ilişskin bir felsefe içeren bir beğeni standardı teorisidir.
} 


\section{Sonuç}

Hume'un Deneme'deki projesinin neden başarısız bir girişim olduğu, onun eleştirmenleri tarafından farklı bağlamlarıyla ayrıntılı bir şekilde tartışıldı. Onun Deneme'deki konumunu eleştirmek kolaydır; bununla birlikte, bu bir yanılgıdır (Townsend 2001: 216). Beğeni standardı çalışmamızda açık kıldığımız içeriğiyle anlaşıldığında, daha açık bir ifade ile onun felsefesinin kavramsal çerçevesinin belirlediği sınırlar içinde anlaşıldığında, Hume'un hem onu arama nedeninin hem de ona ilişkin vardığı sonuçların insan görüşünün ağırlık merkezi ile uygunluğu daha belirgin hale gelmektedir. Şöyle ki, Hume'a göre estetik değer objenin bir niteliği değildir; öznel karaktere sahip bir niteliktir, çünkü güzellik duyguda cisimleşir ve güzellik duygusuna neden olan nitelik, parçaların düzeni ve yapısı ile bağlantılı olarak, duyumun haz üretme gücü tarafindan karakterize edilir. Buna bağlı olarak beğeni yargıları da öznel bir değere atıfta bulunurlar. Hume'un bakış açısından, insan doğası ve doğa arasında önceden kurulmuş uyumun sağladığı öznel-kurucu ilkeler, insanoğlunun güzelliğe duyarlılık veya beğeni inceliği geliştirmesinde hayati bir rol oynar. $\mathrm{Bu}$ nedenle, onun estetik düşüncesinde estetik değerin bir duygu olarak konumlanması insan doğasının beğeni inceliği kazanmasında ilkelerin özneyi nasıl belirlediğini araştırmaya engel değildir. Evrensel ilkelerin imgelem üzerindeki etkisinin yeknesak bir insan doğası ortaya çıkarması, Hume için, bu yeteneği geliştirmenin altyapısını hazırlar. $\mathrm{Bu}$ bağlamda beğenileri incelmiş kişilerin deneyimlerinde ete kemiğe bürünen bir takım özellikler beğeni standardının işaret ettiği gerçekliği temellendirirler. Hume’un zihninde, empirist epistemolojisi ile de uyumlu bir biçimde, onların ortak kararı beğeni anlaşmazlıkları karşısında estetik nitelikler hakkında, beğeni deneyimini geliştiren ve genelleştiren, özneler-arası paylaşıma açık bir estetik açıklık sunduğu için - bu gerçekliğin ta kendisidir. 


\section{KAYNAKÇA}

DELEUZE, Gilles (2001). Empiricism and Subjectivity. An Essay on Hume's Theory of Human Nature, trans. Constantin V. Boundas, New York: Columbia University Press.

FERRY, Luc (2012). Homo Esteticus: Demokrasi Çă̆ında Beğeninin İcadı, çev. Devrim Çetinkasap, İstanbul: Pinhan Yayıncılık.

HUME, David (1960). A Treatise of Human Nature, ed. by L. A. Selby-Bigge, Oxford: Clarendon Press.

HUME, David (1912). An Inquiry Concerning the Principles of Morals, Chicago: The Open Court Publishing Co.

HUME, David (1921). An Inquiry Concerning Human Understanding and Selections form a Treatise of Human Nature, Chicago: The Open Court Publishing Company.

HUME, David (1998). "Of The Standard of Taste", David Hume-Selected Essays, ed. by Stephen Copley \& Andrew Edgar, New York: Oxford University Press.

HÜNLER, Hakkı (2011). Estetik'in Klsa Tarihi, Ankara: Doğu Batı Yayınları.

KIVY, Peter (1967). "Hume's Standard of Taste: Breaking The Circle”, Biritish Journal of Aesthetics, 7(1): 57-65.

KULENKAMPFF, Jens (1990). "The Objectivity of Taste: Hume and Kant", Noûs, 24(1): 93-110.

NUTKU, Uluğ (1998). Insan Felsefesi Çalışmaları, İstanbul: Bulut Yayınları.

NUTKU, Uluğ (2016). Yeniçă̆ Felsefesinde A PRIORI Problemi, Ankara: Doğu Batı Yayınları.

SHELLEY, James (1994). "Hume's Double Standard of Taste”, The Journal of Aesthetics and Art Criticism, 52(4): 437 - 445.

TAŞKIN, Ali (2007). Hume Araştırmaları, İstanbul: Birey Yayıncılık.

TOWNSEND, Dabney (2001). Hume's Aesthetic Theory: Taste and Sentiment, New York and London: Routledge.

WARNOCK, Mary (1978). Imagination, Berkeley and Los Angeles: University of California Press.

WIEAND, Jeffrey (1984). "Hume's Two Standards of Taste", The Philosophical Quarterly, 34(135): 129-142. 